This is the final peer-reviewed accepted manuscript of

Marco Cavalli; Beatrice Goldin; Francesco Comiti; BRARDINONI, FRANCESCO; Lorenzo Marchi: Assessment of erosion and deposition in steep mountain basins by differencing sequential digital terrain models.

GEOMORPHOLOGY, 291. ISSN 0169-555X

DOI: 10.1016/j.geomorph.2016.04.009

The final published version is available online at:

http://dx.doi.org/10.1016/i.geomorph.2016.04.009

Rights / License:

The terms and conditions for the reuse of this version of the manuscript are specified in the publishing policy. For all terms of use and more information see the publisher's website.

This item was downloaded from IRIS Università di Bologna (https://cris.unibo.it/)

When citing, please refer to the published version. 


\title{
Assessment of erosion and deposition in steep mountain basins by differencing sequential digital terrain models
}

\author{
Marco Cavalli ${ }^{\mathrm{a}, *}$, Beatrice Goldin ${ }^{\mathrm{a}}$, Francesco Comiti ${ }^{\mathrm{b}}$, Francesco Brardinoni ${ }^{\mathrm{c}}$, Lorenzo \\ Marchi ${ }^{\text {a }}$ \\ a National Research Council, Research Institute for Geo-Hydrological Protection (CNR IRPI), Padova, Italy \\ ${ }^{\mathrm{b}}$ Faculty of Science and Technology, Free University of Bozen-Bolzano, Bolzano, Italy \\ c Department of Biology, Geology and Environmental Sciences (BiGeA), University of Bologna, Bologna, Italy
}

A R T I C L E I N F O

Keywords:

DoD

LiDAR

Geomorphometry

Debris flow

\section{A B S T R A C T}

Digital elevation models (DEMs) built from repeated topographic surveys permit producing DEM of Difference (DoD) that enables assessment of elevation variations and estimation of volumetric changes through time. In the framework of sediment transport studies, DEM differencing enables quantitative and spatially distributed representation of erosion and deposition within the analyzed time window, at both the channel reach and the catchment scale. In this study, two high resolution Digital Terrain Models (DTMs) derived from airborne LiDAR data ( $2 \mathrm{~m}$ resolution) acquired in 2005 and 2011 were used to characterize the topographic variations caused by sediment erosion, transport and deposition in two adjacent mountain basins (Gadria and Strimm, Vinschgau

Venosta valley, Eastern Alps, Italy). These catchments were chosen for their contrasting morphology and because they feature different types and intensity of sediment transfer processes. A method based on fuzzy logic which takes into account spatially variable DTMs uncertainty, was used to derive the DoD of the study area. Vol umes of erosion and deposition calculated from the DoD were then compared with post event field surveys to test the consistency of two independent estimates. Results show an overall agreement between the estimates, with differences due to the intrinsic approximations of the two approaches. The consistency of DoD with post event estimates encourages the integration of these two methods, whose combined application may permit to overcome the intrinsic limitations of the two estimations. The comparison between 2005 and 2011 DTMs allowed to investigate the relationships between topographic changes and geomorphometric parameters ex pressing the role of topography on sediment erosion and deposition (i.e., slope and contributing area) and de scribing the morphology influenced by debris flows and fluvial processes (i.e., curvature). Erosion and deposition relations in the slope area space display substantial differences between the Gadria and the Strimm basins. While in the former erosion and deposition clusters are reasonably well discriminated, in the latter, char acterized by a complex stepped structure, we observe substantial overlapping. Erosion mostly occurred in areas that show persistency of concavity or transformation from convex and flat to concave surfaces, whereas deposi tion prevailingly took place on convex morphologies. Less expected correspondences between curvature and to pographic changes can be explained by the variable sediment transport processes, which are often characterized by alternation of erosion and deposition between different events and even during the same event.

\section{Introduction}

The appraisal and quantification of sediment dynamics in steep mountain catchments is critical for improving our understanding of geomorphic sediment cascades. Beside the monitoring of sediment fluxes at instrumented channel reaches (e.g., Mathys et al., 2003; McArdell et al., 2007; McCoy et al., 2010; Comiti et al., 2014; Rainato et al., 2016), several methods are available for inferring spatially distributed sediment dynamics from the quantification of geomorphic

\footnotetext{
* Corresponding author at: CNR IRPI, Corso Stati Uniti 4, 35127 Padova, Italy. E-mail address: marco.cavalli@irpi.cnr.it (M. Cavalli).
}

change associated with erosion and deposition (e.g., Brasington et al., 2000; Lane et al., 2003; Wheaton et al., 2010).

The estimation of geomorphic change from repeated surveys was first performed on cross section and longitudinal profiles in order to infer transfer rates from volumetric estimates mainly at the channel unit and the reach scale (Martin and Church, 1995; Ham and Church, 2000; Brewer and Passmore, 2002; Vale and Fuller, 2009). A morphological budget assessment based on multi temporal Digital Elevation Models (DEMs) represents a significant improvement as it overcomes limitations of the traditional approach mainly due to the uncertainty de riving from the interpolation of valley cross section data over larger areas (Lane et al., 1994; Brasington et al., 2000; Fuller et al., 2003; Berger et al., 2011; Bennett et al., 2012). Fuller et al. (2003) 
demonstrated that DEM based comparisons provide more reliable esti mates of sediment transfer compared to discrete cross sections, as the latter can lead to substantial volumetric change underestimation.

When multi temporal DEMs are available, the geomorphic change in time is inferred by DEM of Difference (DoD) grids, in which the elevation difference between old and new surfaces, hence erosion and depo sition, is computed at the cell scale (Lane et al., 2003; Wheaton et al., 2010).

In order to obtain the volumes of eroded and deposited material and compute a sediment budget of a geomorphic system, the elevation dif ference is multiplied by the area of the raster cell. However, several studies have stressed the importance of assessing DEM uncertainty and error propagation to obtain a reliable DoD map (Brasington et al., 2000; Lane et al., 2003; Wheaton et al., 2010; James et al., 2012).

In the last two decades, significant advances, especially in Light De tection And Ranging (LiDAR) technology (Tarolli, 2014 and references therein) have been instrumental for developing new methodologies for the study of geomorphic properties, such as surface roughness (McKean and Roering, 2004; Cavalli and Marchi, 2008), surface texture (Trevisani et al., 2012) and sediment connectivity (Cavalli et al., 2013), as well as for improving DoD reliability (e.g., Wheaton et al., 2010; Theule et al., 2012; Anders et al., 2013; Croke et al., 2013; Picco et al., 2013; Vericat et al., 2014).

Recent studies have demonstrated the capability of DEM differencing for assessing areal and volumetric changes in relatively short gravel bed channel reaches undergoing ordinary flows, by means of Terrestrial Laser Scanning (TLS) (Picco et al., 2013), and for larger areas, encompassing channel and inundated floodplain affected by a catastrophic flood, through Airborne Laser Scanning (ALS) (Croke et al., 2013); both studies have considered the spatial variability of the vertical error affecting TLS and ALS derived surface in DoD analysis. Also, the morphological changes associated to river restoration in a single thread Alpine river were analyzed by differencing DEMs obtained through bathymetric ALS (Campana et al., 2014). James et al.(2012) have utilized detailed historical topographic surveys (older than 70 years) to derive LiDAR derived Digital Terrain Models (DTMs) in a gully system and in two large rivers and compared these with more recent (and more accurate) DTMs through DoD analysis, and have demonstrated that DoD analysis in gully and large riverine systems can be extended to several decades, if accurate historical data are avail able and the investigated geomorphic change is larger than DoD uncertainties.

DEM differencing was successfully applied for monitoring mass wasting processes (see Jaboyedoff et al., 2012 for a review), permitting to identify patterns of erosion and deposition and quantify relevant mo bilized volumes (e.g., Corsini et al., 2007; Scheidl et al., 2008; Baldo et al., 2009; Bull et al., 2010; Bremer and Sass, 2012; DeLong et al., 2012; Bossi et al., 2015). The combined use of remote sensing and DEM differencing can improve the assessment of volumetric sediment budget associated with debris flows, helping the prediction of the magnitude of such

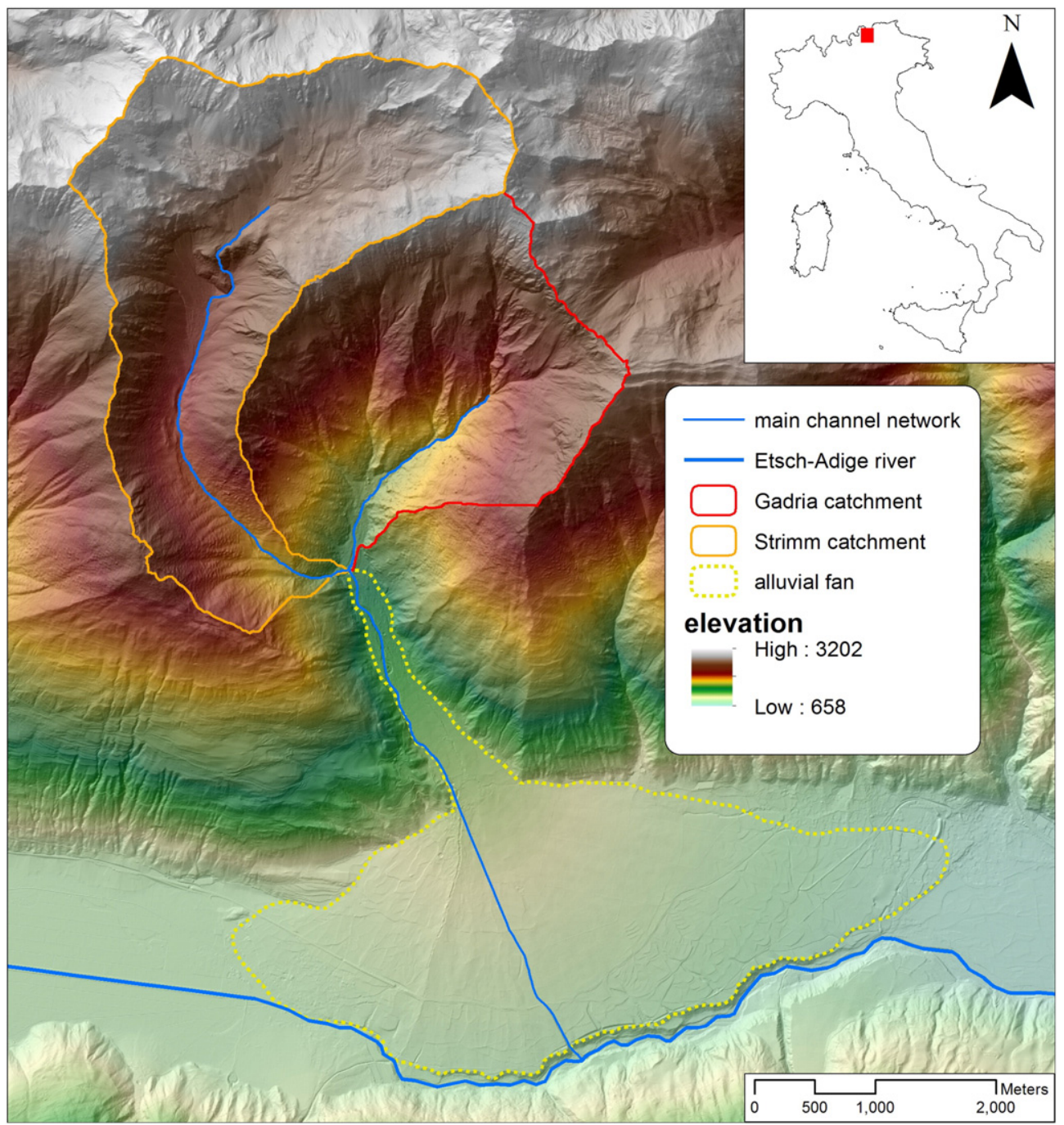

Fig. 1. Location and topographic map of the Gadria and Strimm catchments. 


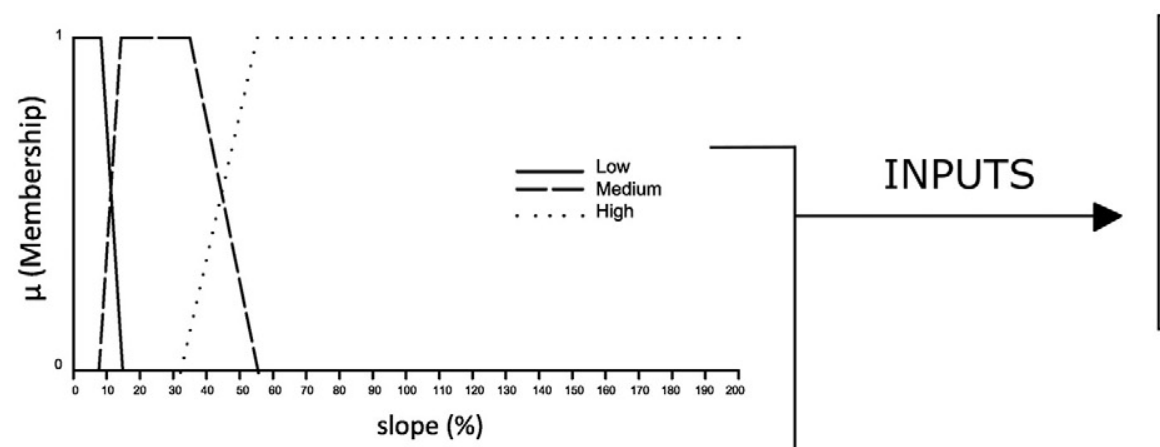

\section{FUZZY \\ INFERENCE \\ SYSTEM}

Type: Mamdani

And Method: Max

Implication: Min

Aggregation: Max
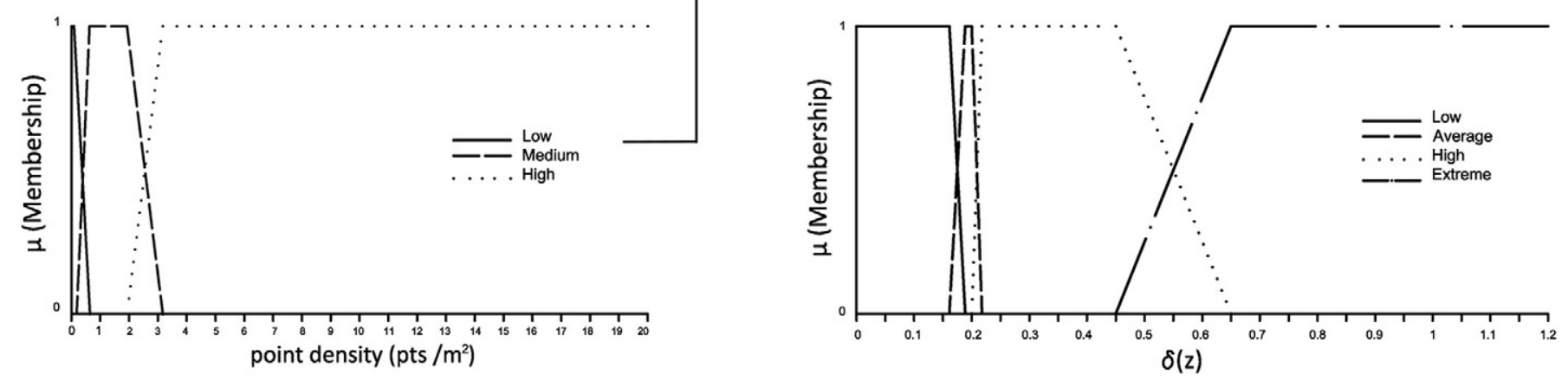

Fig. 2. Inputs (slope and point density) and output (elevation uncertainty $\delta z$ ) fuzzy membership functions used in the present study.

events (Scheidl et al., 2008; Theule et al., 2012; Blasone et al., 2014). DoD can be particularly useful for quantifying hillslope erosion in semi arid regions (e.g., Coe et al., 1997), where field measurements are usually difficult due to the low frequency and localized occurrence of rainfall events causing sediment transfer.

The DEM differencing analysis was also widely applied in glacial, proglacial and periglacial environments (e.g., Abermann et al., 2010; Karimi et al., 2012). Also in this context, a robust analysis encompassing DTM uncertainty evaluation and error propagation is considered funda mental (Joerg et al., 2012; Sailer et al., 2012).

Despite the now relatively large number of studies which have utilized the DoD methodology to quantify sediment transport processes, to our knowledge none of them have addressed the analysis of primary and secondary geomorphometric parameters (Hengl and Reuter, 2009). These parameters control the spatial distribution of geomorphic process domains (Montgomery and Foufoula Georgiou, 1993; Brardinoni and Hassan, 2006) and are expected to dictate topographic changes over time.

In the light of such research gap, in this work we aim to:

compare erosion and deposition assessed by differencing two LiDAR derived DTMs considering a spatially distributed DoD uncertainties with post event field surveys in two small mountain catchments dominated by different geomorphic processes (i.e., debris flow versus bedload transport); investigate the causal linkages between DoD topographic changes and key geomorphometric attributes including upslope area, local slope, and topographic curvature (planform and profile).

\section{Study areas and LiDAR data}

\subsection{Test catchments}

The study areas are the Gadria $\left(6.3 \mathrm{~km}^{2}\right)$ and Strimm Strimo $\left(8.5 \mathrm{~km}^{2}\right)$ basins, two adjacent catchments located in the upper Vinschgau Venosta valley, Italy (Fig. 1). The two catchments differ distinctively in terms of dominant sediment transfer processes and their contrasting morphology leads to different patterns of sediment connectivity, showing a higher efficiency of sediment routing in the Gadria catchment (Cavalli et al., 2013). The Gadria catchment features a maximum elevation of $2945 \mathrm{~m}$ a.s.l., an average slope of $79.1 \%$, and shows a high frequency of debris flows along the channel network due to the combination of steep morphology, highly deformed metamorphic rocks and thick glacio fluvial deposits. The Strimm basin (maximum el evation $3197 \mathrm{~m}$ a.s.l., average slope $61.8 \%$ ) features mainly bedload transport; debris flows may occur only rarely in the downstream reach of the main channel (possibly 12 in the last 100 years, based on historical records), but quite frequently in the tributaries in the mid dle sector of the catchment. At the confluence of Gadria and Strimm catchments (1394 m a.s.l.), an artificial debris retention basin $\left(40,00060,000 \mathrm{~m}^{3}\right.$ in volume, Comiti et al., 2014) equipped with a filter check dam, was built in the 1970s. Further downstream, a large alluvial fan $\left(10 \mathrm{~km}^{2}\right)$ connects the Gadria and Strimm catchments to the Etsch Adige River valley floor.

Both catchments are dominated by methamorphic lithologies. In the upper and mid portions of the study area paragneiss and schist outcrop, with abundant metapegmatites of the Matsch/Mazia unit (Habler et al., 2009). The lower part is underlain by paragneiss and orthogneiss of the Öztal unit, which in places were reduced to phyllonite due to cataclastic

Table 1

Rules definition scheme for the two-input FIS used to evaluate geomorphic changes in the Gadria and Strimm basins.

\begin{tabular}{|c|c|c|c|}
\hline \multirow[t]{2}{*}{ Rule } & \multicolumn{2}{|l|}{ Input } & \multirow{2}{*}{$\begin{array}{l}\text { Output } \\
\delta z \\
m\end{array}$} \\
\hline & $\begin{array}{l}\text { Slope } \\
\%\end{array}$ & $\begin{array}{l}\text { Point density } \\
\text { pts } \mathrm{m}^{2}\end{array}$ & \\
\hline 1 & Low & Low & Average \\
\hline 2 & Low & Medium & Low \\
\hline 3 & Low & High & Low \\
\hline 4 & Medium & Low & High \\
\hline 5 & Medium & Medium & Average \\
\hline 6 & Medium & High & Average \\
\hline 7 & High & Low & Extreme \\
\hline 8 & High & Medium & Extreme \\
\hline 9 & High & High & High \\
\hline
\end{tabular}


Table 2

Correspondence between the sign of planform and profile curvature values surface convexity/concavity.

\begin{tabular}{lllll}
\hline & \multicolumn{2}{l}{ Planform curvature } & \multicolumn{2}{l}{ Profile curvature } \\
\hline Sign & $($ ) & $(+)$ & $(~)$ & $(+)$ \\
Surface & Convex & Concave & Concave & Convex \\
\hline
\end{tabular}

deformation related to the Vinschger shear zone (Corrado Morelli, personal communication, 2015, based on unpublished data of the CARG project, Autonomous Province of Bozen Bolzano).

Mean annual precipitation in the Vinschgau valley floor is around $500 \mathrm{~mm}$, with maxima in the summer season when most of the debris flows typically occur. Precipitation increases rapidly with eleva tion, reaching around $700 \mathrm{~mm}$ at about $1800 \mathrm{~m}$ a.s.l., and around 800900 $\mathrm{mm}$ (Comiti et al., 2014) above $2000 \mathrm{~m}$ a.s.l. Typically, snow cover lasts from mid November to mid April on most of the study areas, and until the early summer at the Strimm headwaters.

Vegetation cover mainly includes mixed spruce larch stands in the middle and southern portions of the catchments, whereas Alpine meadows and pastures are widespread above the timberline. Bare rocks and debris dominate the upper parts of the catchments.

\subsection{LiDAR data sets}

LiDAR data used to derive the 2005 DTM was part of a data set that cover the whole territory of the Autonomous Province of Bozen Bolzano. The entire Province was covered by different flights between summer 2004 and winter 2006 carried out using an Optech ALTM 3033 scanner and a Falcon II sensor. The surveyed area was divided into three sections with different point density standards (Wack and Selzl, 2005). The Gadria and Strimm basins, surveyed on July 2005, were included within the second (areas below $2000 \mathrm{~m}$ a.s.l.) and the third one (areas above $2000 \mathrm{~m}$ a.s.l.) where the minimum survey design point density of the last pulse was 8 points and 3 points per 5 $\times 5 \mathrm{~m}$, respectively.

In 2011, the Free University of Bozen Bolzano and the CNR IRPI has contracted a high point density ( $>8$ points $\mathrm{m}^{-2}$ ) LiDAR survey over the Gadria and Strimm basins in order to obtain an accurate and high resolution DTM. The survey was carried out on July 2011 using a Riegl LMS Q560 sensor mounted on a Piper Seneca II. High resolution ( 0.25 $\mathrm{m}$ ) orthophotos were also acquired with a Canon EOS 1Ds Mark III during the LiDAR survey.

Both raw point clouds were filtered into bare ground points using the Terrascan ${ }^{\mathrm{TM}}$ software classification routines and algorithms. Filtered point density was 0.51 and 2.28 points $\mathrm{m}^{-2}$ for 2005 and 2011, respec tively. Bare ground points were then interpolated using natural neigh bor algorithm to derive two DTMs with a homogeneous resolution of $2 \mathrm{~m}$. The RMSE (root mean square errors), calculated by comparing GPS elevation points collected in morphologically unchanged areas and the corresponding DTM cell values, resulted $0.29 \mathrm{~m}$ for the 2005 DTM and $0.16 \mathrm{~m}$ for the $2011 \mathrm{DTM}$.

The alignment of 2005 and 2011 point clouds, a key processing step since it was demonstrated to have significant impact on sediment budgeting through DoD analysis (e.g., Lallias Tacon et al., 2014; Schaffrath et al., 2015), was performed by a private firm using the

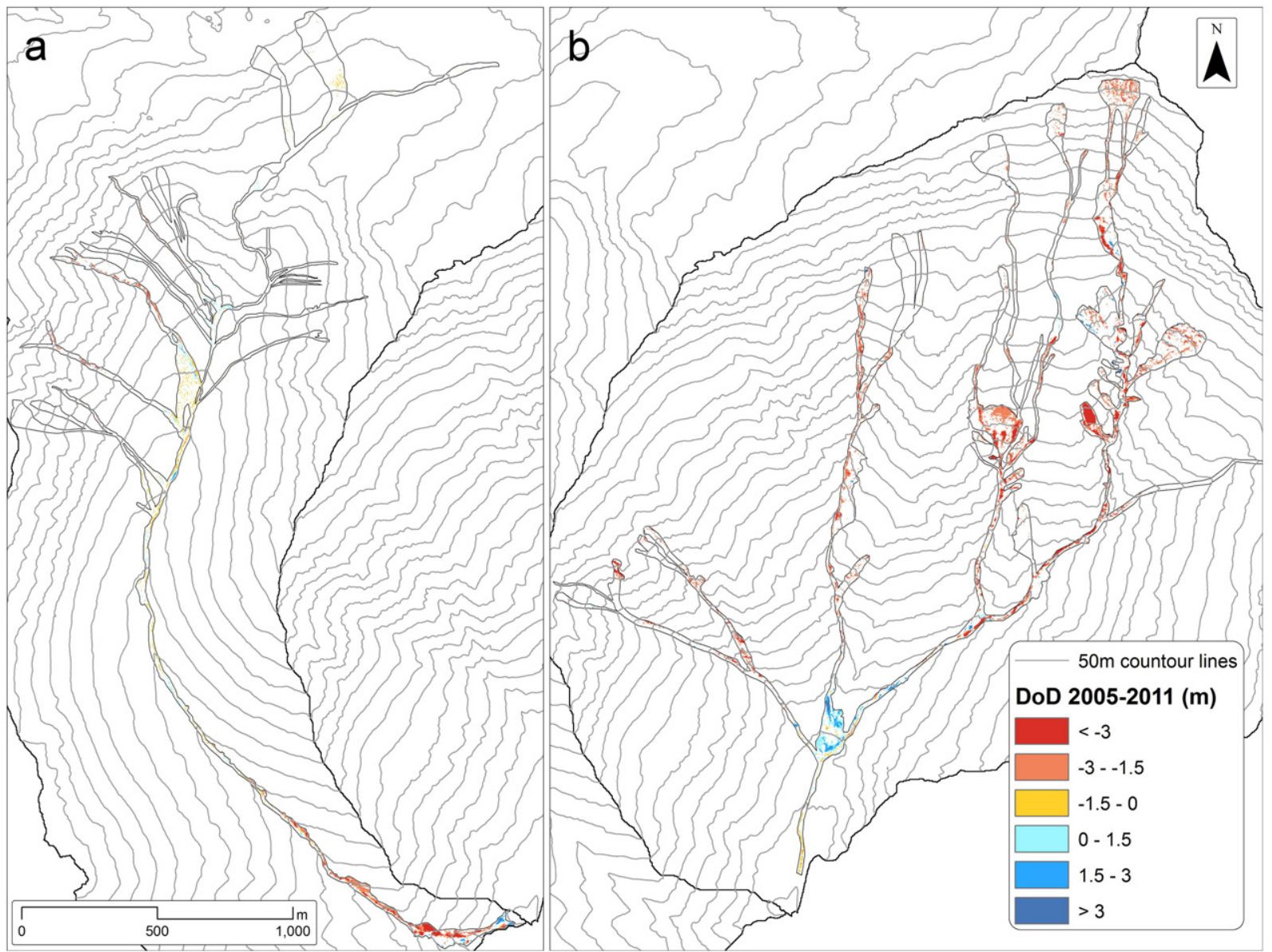

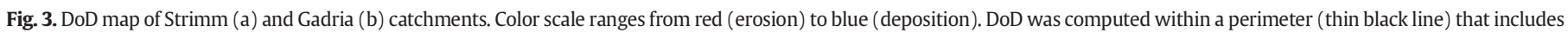
areas featuring evidence of geomorphic activity as interpreted via photo interpretation and field surveys. 


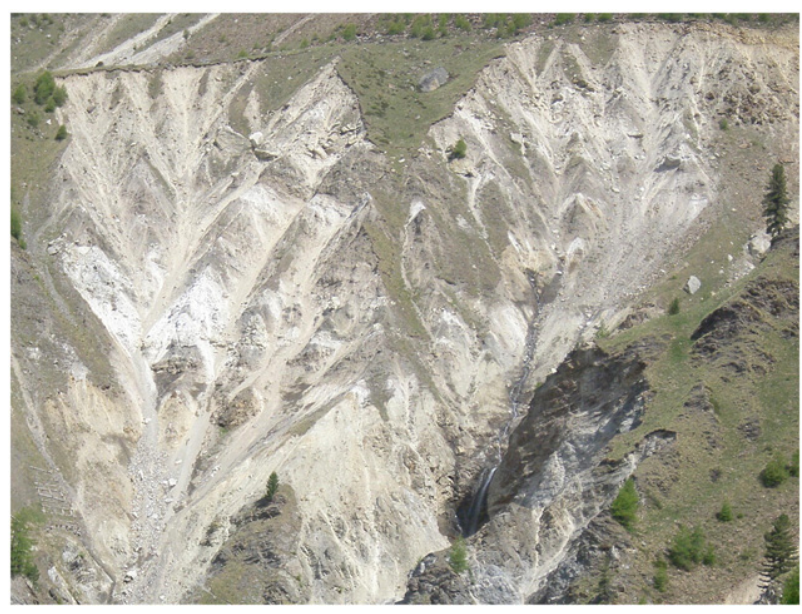

Fig. 4. Erosion on the hillslope and in the gullies of the upper part of the Gadria catchment.

iterative closest point algorithm of the PolyWorks software (http:// inovmetric.com) on selected stable surfaces.

\section{Methods}

\subsection{DEM of Difference (DoD)}

Given the heterogeneity in quality and accuracy of the two available DTMs, as well as because of the complex morphology of the study area, a robust approach for the assessment of geomorphic changes and the es timation of erosion and deposition volumes was deemed necessary to discriminate the actual changes in surface elevation from noise. In order to take into account DoD uncertainties, we have followed the three main steps proposed by Wheaton et al. (2010) that include (i) estimating the magnitude of individual DTM uncertainty in a spatial ly variable way using the technique based on fuzzy set theory; (ii) prop agating the identified uncertainties into the DoD, and (iii) assessing the significance of the propagated uncertainty. The spatially variable uncertainty assessment was addressed by creating ad hoc Fuzzy Inference Systems (FIS) (Wheaton et al., 2010) using two input parameters as proxies for vertical uncertainty in the DTM: one related to topography (i.e., slope) and one related to survey proper ties (i.e., point density) (Fig. 2 and Table 1). The first step to create the FIS was to define Membership Functions (MFs) for the input variables (i.e., point density and slope) and it was carried out by identifying three classes (Low, Medium, High) setting a range of values for each class (Fig. 2). The second steps required the definition of the rules relat ing inputs to outputs (Table 1). The last component of the FIS was the definition of the MF for the elevation uncertainty $(\delta z)$ output variable, which was obtained by defining four classes (Low, Average, High, Ex treme) and the relative range of values (Fig. 2). These functions were

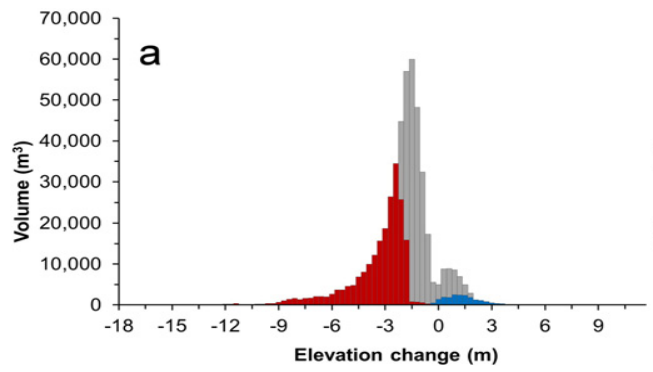

calibrated for each parameter to the observed ranges of variability assigning to high point density a higher weight influencing uncertainty (Table 1 ).

Considering the quality of the old (2005) and new (2011) surface, fuzzy surfaces were calculated by applying different intervals to the out put values. Specifically, MFs range from 0.14 to 1.2 for 2005 DTM and from 0.10 to $1.2 \mathrm{~m}$ for 2011 DTM. A maximum value of $1.2 \mathrm{~m}$ was cho sen according to estimated elevation vertical error on high slope and low point density area. At the end, a map of spatially variable elevation uncertainty was obtained for each DTM.

Following the approach by Brasington et al. (2003) and Lane et al. (2003), in turn based on Taylor (1997), and assuming a normal distribution of errors, individual errors in the DTMs were then propagated into DoD according to the equation:

$\mathrm{U}_{\text {crit }} \mathrm{t} \sqrt{ }\left(\delta z_{\text {new }}\right)^{2}+\left(\delta z_{\text {old }}\right)^{2}$

where $U_{\text {crit }}$ is the critical threshold error in the DoD, or Level of Detec tion (LoD) of significant elevation change, with $\delta z_{\text {new }}$ and $\delta z_{\text {old }}$ being respectively the elevation uncertainty in the new (2011) and the old (2005) DTM. $U_{\text {crit }}$ is based on a critical student's t value at a chosen confidence interval where:

$\mathrm{t} \frac{\left|\mathrm{z}_{\mathrm{DEM}_{\text {new }}} \mathrm{z}_{\mathrm{DEM}_{\text {old }}}\right|}{\delta \mathrm{u}_{\text {DoD }}}$

where $\delta \mathrm{u}_{\mathrm{DoD}}$ is the propagated error in the $\operatorname{DoD}\left|z_{D E M_{\text {new }}} z_{D E M_{\text {old }}}\right|$ is the absolute value of the DoD.

In this study, the $90 \%$ confidence interval was used as a threshold. For each DoD raster cell, a critical threshold error was then calculated with Eq. (1) to derive a LoD which was finally subtracted from all DoD cells to derive maps of significant elevation change and calculate volumes of erosion and deposition.

To derive the 20052011 DoD map according to the above mentioned methodology, we used the GCD 5 software ArcGIS plugin developed by Wheaton et al. (2010).

To avoid additional noise, since this study is chiefly concerned with topographic changes associated with channelized processes (i.e., debris flows, debris floods and fluvial transport), we have restricted the DoD analysis to a manually delineated terrain perimeter. The perimeter was drawn on a digital orthophoto mosaic so that it included geomor phic activity identified from visual inspection of sequential aerial photo sets (i.e., 2000, 2006, 2008 and 2011) and extensive fieldwork conducted in the summers of 2010 and 2011 (Brardinoni et al., 2012b). The focus on sediment processes occurring in channels and sed iment supply from hillslopes coupled to channels has enabled compar ison of DoD results with data on sediment deposits gathered by means of post event surveys (see next section).

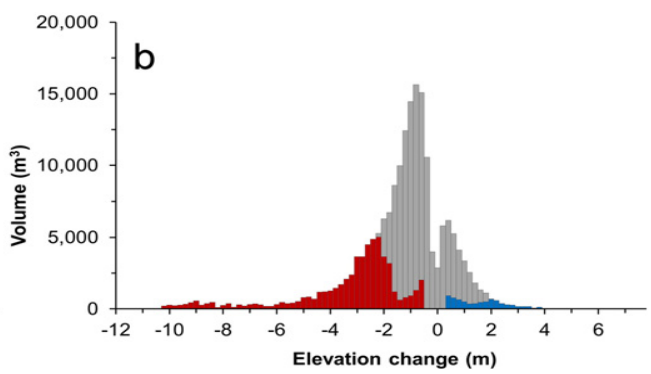

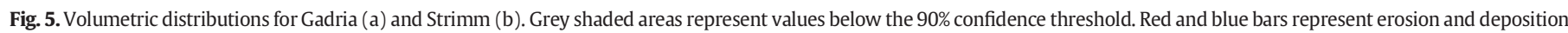
respectively. 


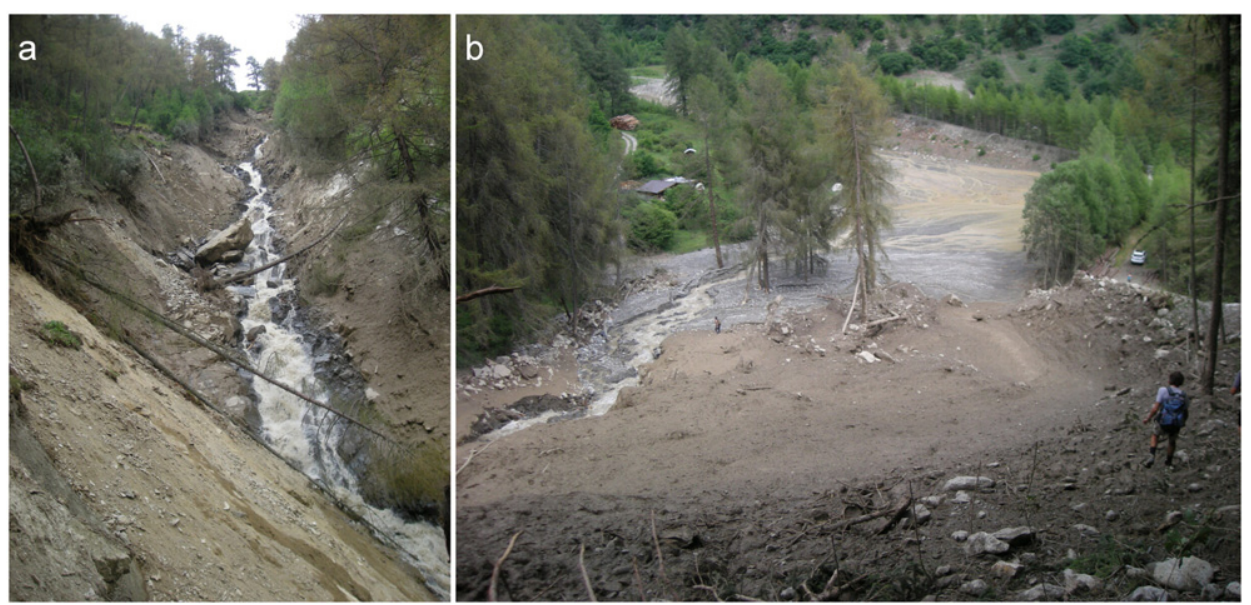

Fig. 6. Effects of the debris flow of July 12, 2010 in the lower part of Strimm Creek: a) deep channel incision triggering landslides on the banks; b) flow avulsion just upstream of the retention basin.

\subsection{Post event sediment data}

The 20052011 DoD volumetric change estimates were compared against independent, field based volumetric measurements of debris flow deposits. These measurements are part of an historical, region wide inventory of debris flows and flood events implemented by the Autonomous Province of Bozen Bolzano.

For the comparison with DoD results, only the information on the events occurred in the Gadria and Strimm catchments from 2005 to 2011 (i.e., the years of the LiDAR surveys) were considered.

In the Gadria and Strimm basins, event magnitude was estimated during field surveys by measuring the deposits in the retention basin present at the outlet, and in deposition areas along the channels. Since most of transported sediment stops in the retention basin and the material is periodically cleaned out, this area was excluded from the DoD analysis. The field estimated deposition volumes in the retention basin were summed to the volumes of deposits within the catchments to assess the total eroded sediment during all the events occurred with in the analyzed time span. This estimation was then compared to the erosion derived from DoD analysis for the same period. Accordingly, DoD deposition was compared with the volumes surveyed in the field deposited in areas within the catchments.

\subsection{Geomorphometry}

Slope area plot derived from the 2005 DTM, representing the morphology before the events that induced the investigated geomorphic changes, was combined to erosion and deposition pattern derived from DoD analysis. Slope and contributing area were derived from the DTMs using TauDEM 5.1 (http://hydrology.usu.edu/taudem/ taudem5/index.html). The contributing area was calculated using the D infinity flow algorithm (Tarboton, 1997) after filling local depression in the DTM. D infinity algorithm was chosen because it better approximates flow routes on hillslopes (Cavalli et al., 2013) avoiding, at the same time, unrealistic dispersion if compared to other multiple flow algorithms (Tarolli and Dalla Fontana, 2009). Accordingly, slope was computed as the steepest outwards slope along the D infinity flow direction. Slope values were averaged for constant intervals $\left(100 \mathrm{~m}^{2}\right)$ of drainage area.

Geomorphometric analysis has involved also surface curvature, which was calculated on the same perimeter used for erosion and depo sition assessment along the channel network. Surface curvature was then compared to the DoD estimated changes. The aim of this analysis is to investigate changes in curvature both in the direction of maximum slope (i.e., profile curvature) and perpendicularly to it (i.e., planform curvature). Curvature signs can vary according to different computation methods. In this study, planform and profile curvatures were derived using Landserf software (http://www.landserf.org/) that is based on Wood's algorithm (Wood, 1996) (Table 2). Values between -0.2 and 0.2 for planform curvature and -0.02 and 0.02 for profile curvature were ascribed to flat areas.

\section{Results}

\subsection{DEM of Difference (DoD)}

The DoD maps obtained as illustrated in Section 3 for the Gadria and Strimm basins (Fig. 3 ) permit to see at a glance the different spatial pat tern of geomorphic change in the two catchments.

The upper part of Gadria catchment is characterized by widespread erosion (Fig. 4). In sediment source areas on hillslopes and gullies, 20052011 elevation differences range from $-1.45 \mathrm{~m}$ to $-9 \mathrm{~m}$,

Table 3

Volumes derived from historical database related to events occurred in the Gadria basin in the period 2005-2011; *Uncertain date.

\begin{tabular}{|c|c|c|c|c|}
\hline \multirow[t]{2}{*}{ Type of process } & \multirow[t]{2}{*}{ Date } & \multicolumn{3}{|c|}{ Volume $\left(\mathrm{m}^{3}\right)$} \\
\hline & & $\begin{array}{l}\text { Deposition } \\
\text { within the } \\
\text { catchment }\end{array}$ & $\begin{array}{l}\text { Deposition } \\
\text { at } \\
\text { the } \\
\text { retention } \\
\text { basin }\end{array}$ & $\begin{array}{l}\text { Total } \\
\text { erosion }\end{array}$ \\
\hline \multicolumn{5}{|l|}{ Gadria } \\
\hline Not known & $2006^{*}$ & & 700 & 700 \\
\hline Debris flow & $18 / 05 / 2006$ & & 10,000 & 10,000 \\
\hline Debris flow & $25 / 07 / 2006$ & & 35,000 & 35,000 \\
\hline Debris flow & $10 / 08 / 2007 *$ & & 7000 & 7000 \\
\hline Debris flow & 06/08/2008* & 11,900 & 27,100 & 39,000 \\
\hline Debris flow & $24 / 07 / 2009$ & 3200 & 35,000 & 38,200 \\
\hline \multirow[t]{3}{*}{ Debris flow } & $12 / 07 / 2010$ & 1000 & 20,000 & 21,000 \\
\hline & & Total & Total & Total \\
\hline & & 16,100 & 134,800 & 150,900 \\
\hline \multicolumn{5}{|l|}{ Strimm } \\
\hline $\begin{array}{l}\text { Debris flow - it did not reach } \\
\text { catchment outlet Bedload }\end{array}$ & $06 / 08 / 2008$ & 1000 & & 1000 \\
\hline Debris flood & $24 / 07 / 2009$ & & 3000 & 3000 \\
\hline Debris flow & $13 / 06 / 2010$ & 700 & & 700 \\
\hline Debris flood & $12 / 07 / 2010$ & 10,000 & 15,000 & 25,000 \\
\hline \multirow[t]{4}{*}{ Bedload } & 01/10/2010* & & 3500 & 3500 \\
\hline & $27 / 05 / 2011$ & & 2500 & 2500 \\
\hline & & Total & Total & Total \\
\hline & & 11,700 & 24,000 & 35,700 \\
\hline
\end{tabular}


Table 4

Volumes calculated with DoD approach compared with historical database for the Gadria and Strimm catchments. The DoD error volume was computed per each pixel on the base of uncertainties calculated with Eq. (1).

\begin{tabular}{|c|c|c|c|c|}
\hline & $\begin{array}{l}\text { Post-event field } \\
\text { estimate }\end{array}$ & DoD & & $\begin{array}{l}\text { DoD error } \\
\text { volume }\end{array}$ \\
\hline \multicolumn{5}{|l|}{ Gadria } \\
\hline Total erosion $\left(\mathrm{m}^{3}\right)$ & 150,900 & 218,961 & \pm & 86,414 \\
\hline Deposition within the catchment $\left(\mathrm{m}^{3}\right)$ & 16,100 & 20,955 & \pm & 6909 \\
\hline \multicolumn{5}{|l|}{ Strimm } \\
\hline Total erosion $\left(\mathrm{m}^{3}\right)$ & 35,700 & 57,331 & \pm & 18,562 \\
\hline Deposition within the catchment $\left(\mathrm{m}^{3}\right)$ & 11,700 & 7539 & \pm & 3406 \\
\hline
\end{tabular}

whereas erosion in the channel main stem ranges from -0.45 to

$-13 \mathrm{~m}$. A $6 \mathrm{~m}$ thick, large deposition area is observed in the lower part of the catchment main stem, at the confluence with the western most tributary. Conversely, in the Strimm basin erosion occurred especially in the downstream most reach of the main channel, where erosion depth reached values of $10 \mathrm{~m}$. Some less marked erosion can be identified along the small debris flow channels on the right slopes of the catchment (Fig. 3). Deposition mainly occurred in the distal part of those steep tributaries where debris flows tend to deposit most of the sediment. Also, some deposition in the Strimm is evident in the in termediate reach of the main channel. Overall, erosion areas cover $9.6 \%$ and $18 \%$ of the analyzed surface (i.e., within the perimeter described above) of Strimm and Gadria basins, respectively, and correspond to $0.31 \%$ and $0.94 \%$ of the total catchment areas.

Beside the spatial pattern, also the volumetric change distributions turn out different in the two basins (Fig. 5), with the Gadria displaying a markedly unimodal distribution, with a peak at low magnitude ero sion values, whereas the Strimm is characterized by a bimodal distribu tion with two peaks of erosion. The peak at higher erosion values in the Strimm basin derives from a complex event occurred in July 2010, which caused channel incision and landsliding due to bank undercut ting in the downstream most channel reach, just upstream of the reten tion basin (Fig. 6). This was the largest erosion event occurred in the Strimm catchment during 20052011 study period (Table 3), and the largest at least since the 1930 s based on the historical events database. From the histograms shown in Fig. 5, the relatively high magnitude of "lost" information close to the null elevation change value can be ob served, due to the application of a DoD threshold for the evaluation of uncertainty as described in Section 3.

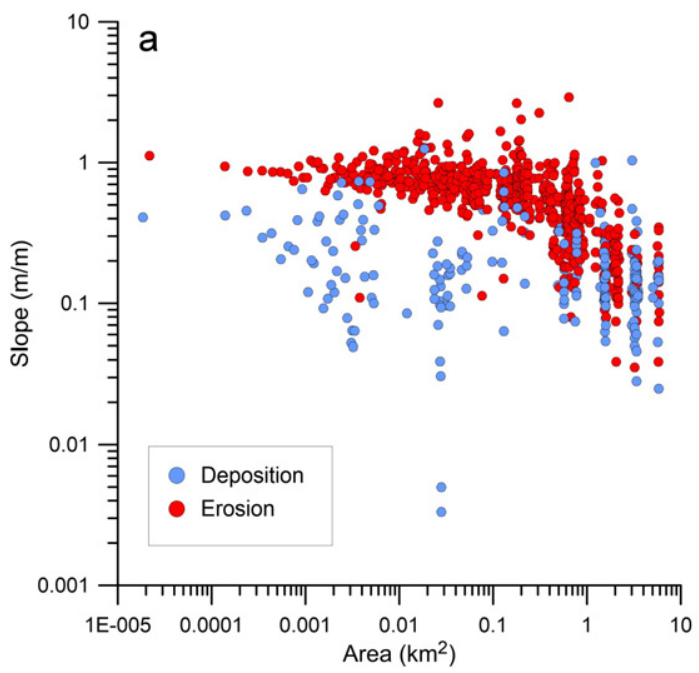

The recorded geomorphic events occurred from July 2005 to June 2011 in Gadria and Strimm basins, and the relative volume estimates, are reported in Table 3, and the comparison between DoD analysis and field based volumes is shown in Table 4. As explained in the methods section, deposits mapped and measured during the post event surveys were compared with DoD estimated deposits, whereas erosion computed by means of DoD analysis was compared with total erosion resulting from field surveys, i.e., the sum of sediment volumes deposited within the catchment plus the sediment that settled in the re tention basin.

In general, DoD volumes are generally larger than field estimates, with the only exception of deposits within the catchment in the Strimm, where we observe the opposite.

\subsection{Relation between geomorphometry and geomorphic changes}

The area slope relation (Fig. 7) was analyzed within the same perim eter delineated for the volumetric quantification of sediment transfer (Fig. 3). Thus, although slope and contributing area were calculated for the whole catchment, plotted data refer only to the buffer zone drawn around the channel network (Fig. 3). It is evident how the pat tern of erosion deposition, as detected by DoD analysis, differs in two basins, reflecting their different topographic settings. In the Gadria basin (Fig. 7a), where erosion processes can be observed in the field along most of the channel network, the pattern of erosion in the area slope mimics the typical topographic signature of debris flow dominat ed catchments (e.g., Montgomery and Foufoula Georgiou, 1993). The pattern of erosion in the Strimm catchment does not show an evident decrease of slope values between 0.1 and $1 \mathrm{~km}^{2}$ as in the Gadria: this can be ascribed to both less continuous occurrence of erosion along the channel network and on adjacent slopes, and to the complex, stepped, long profile of the main channel, which is characterized by steep slopes in its downstream most reach. As it was expected, al though local conditions may led to debris accumulation also on high gradient areas, deposition areas feature lower slopes than erosion areas do in both catchments. This result is more evident in the Gadria ( 0.61 and $0.20 \mathrm{~m} / \mathrm{m}$ average slope values for erosion and deposition, re spectively) than in the Strimm basin $(0.29$ and $0.27 \mathrm{~m} /$ $\mathrm{m}$ average slope values for erosion and deposition, respectively).

Strimm area slope plot (Fig. 7b) shows two main erosional domains: the first, for drainage areas $<0.4 \mathrm{~km}^{2}$, refers to debris flow activity along the tributaries, whereas the second one, for drainage areas $>5 \mathrm{~km}^{2}$, rep resents the main channel downstream of the hanging valley. Pro nounced erosion at high drainage area values correlate well with the

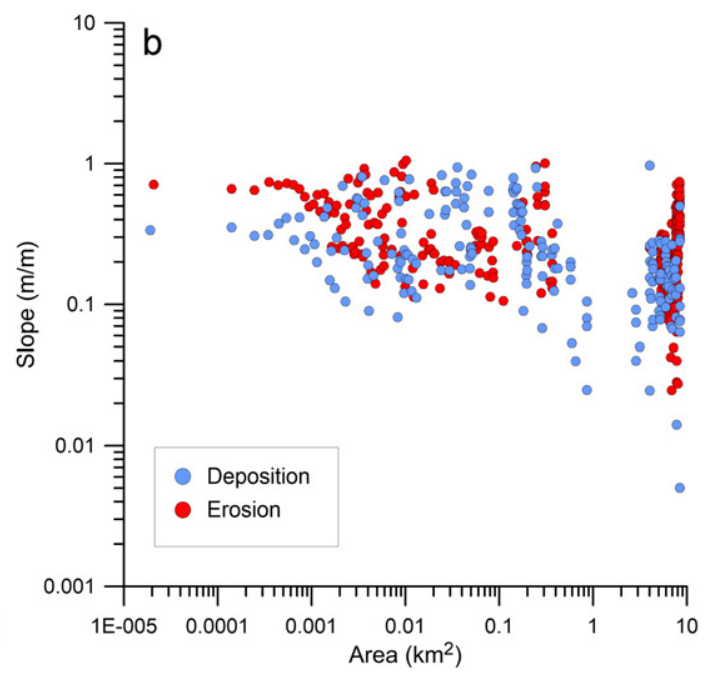

Fig. 7. Illustration of the relationship between drainage area and local slope and DoD-detected changes for Gadria (a) and Strimm (b) basins. 

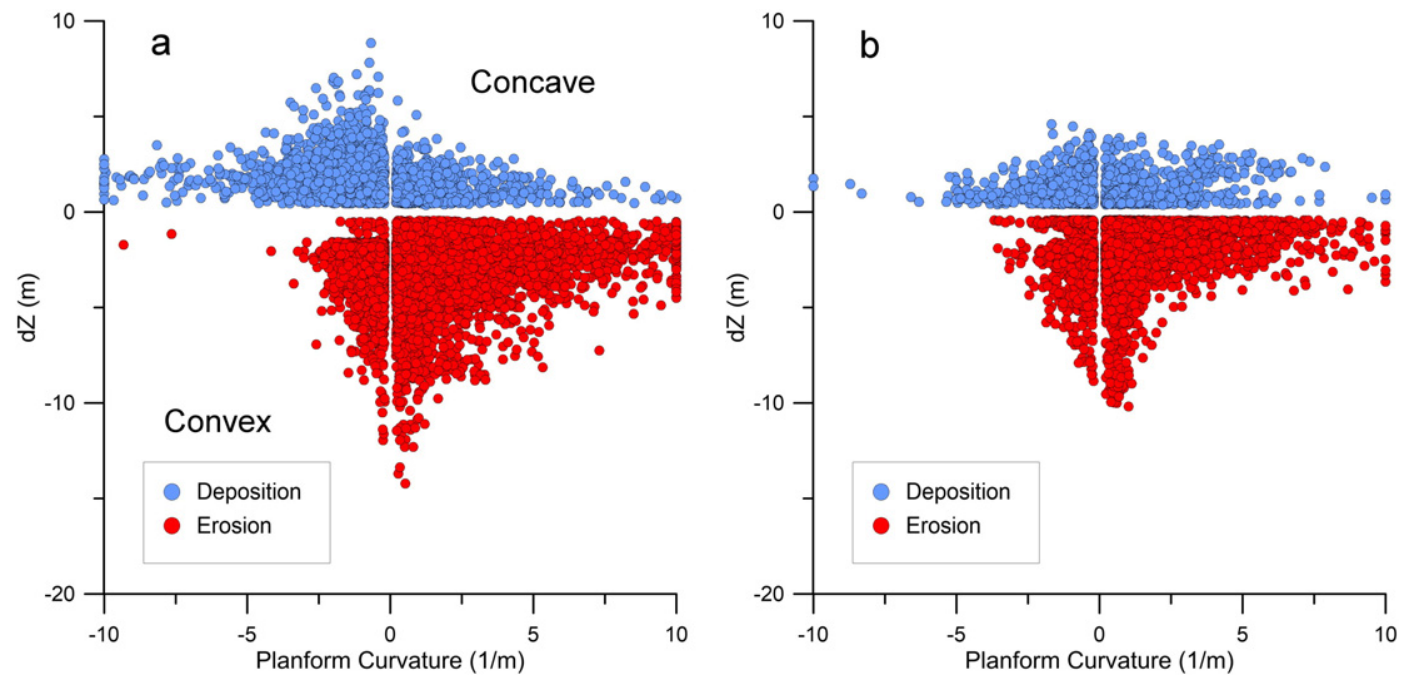

Fig. 8. Gadria (a) and Strimm (b) planform curvature derived from the 2011 DTM and compared to erosion (red) and deposition (blue) processes as predicted by the DoD.

effects of the debris flow of July 12, 2010 in the downstream most reach of the Strimm. Several deposits in the Strimm catchment are associated with high slope values (i.e., up to $45^{\circ}$ ) in the first domain of the area slope plot (Fig. 7b). This is mainly related to sediment mobilization on steep talus cones and talus slopes, and to several deposits consisting of lateral levees and lobes associated with debris flows on the western most tributaries. Similar depositional values, even though at first glance may seem too high, agree with the slope range (i.e., from $2.30^{\circ}$ to $52^{\circ}$ ) of landslide termini mapped in the Tsitika and Eve River basins, Vancouver Island (Brardinoni et al., 2009). The main consequence of this deposi tional pattern is that we observe substantial overlapping between the erosional and depositional envelopes in the area slope plots of the Strimm (Fig. 7b) and, partially, of the Gadria (Fig. 7a), which compli cates our ability to remotely predict erosion and deposition by means of these two geomorphometric variables.

Planform and profile curvature, computed on a moving window of $5 \times 5$ cells for the 2011 DTM, were plotted versus elevation difference between 2011 and 2005 (Figs 8 and 9). Erosion prevails on positive values of planform curvature, which correspond to concave features (67 and 53.9\% for Gadria and Strimm, respectively), while the majority of deposition areas occur on convex features (60.2 and 51\% for Gadria and Strimm, respectively).

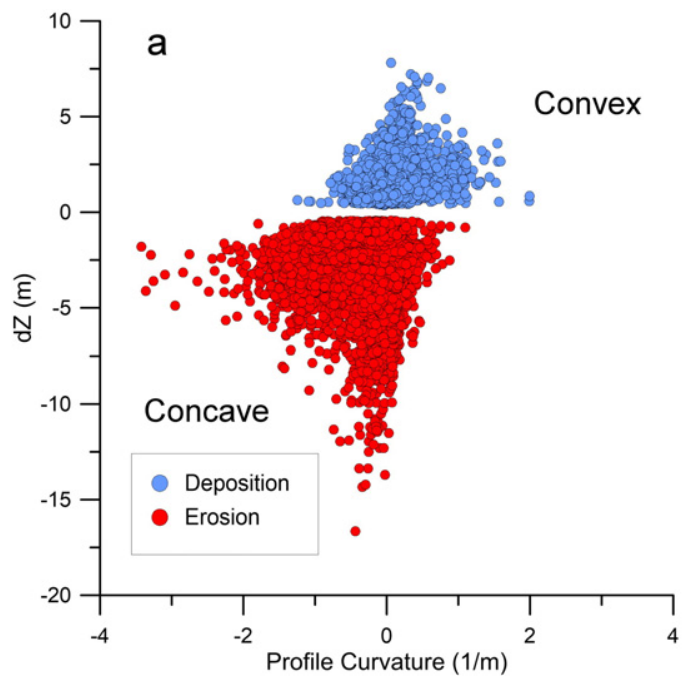

A similar pattern is observed for profile curvature (Fig. 9); we recall that the signs for convexity and concavity are opposite from that of planform curvature (Table 2). Erosion prevails on concave areas (67.3 and 55.3\% for Gadria and Strimm respectively) and deposition mainly occurs on areas of convex profile curvature (60.4 and $43.8 \%$ for Gadria and Strimm, respectively).

In order to analyze the relations between topographic variations and the temporal evolution of concavity and convexity, planform and profile curvature were derived from 2005 DTMs with the same windows size (i.e., $5 \times 5$ cells) chosen for curvature analysis on the 2011 DTMs. Tables 5 and 6 report the proportion of convex, concave and flat features changing in areas where DoD showed both negative elevation (i.e. ero sion) and positive (i.e. deposition) differences.

In Gadria catchment, erosion prevails in locations that experienced an increase in planform concave morphology both in flat $(12.5 \%)$ and concave surface (45\%). Results for Strimm basin are similar to those de rived for Gadria, with comparable values of concavity changes in flat $(12.2 \%)$ and concave area (50.5\%). For both catchments, the highest amount of deposition occurs in locations featuring a change from con cavity to convexity (25.1\% and $34.1 \%$ for Gadria and Strimm basins, re spectively) or an increase in convexity (23.7\% for Gadria and $21 \%$ for Strimm).

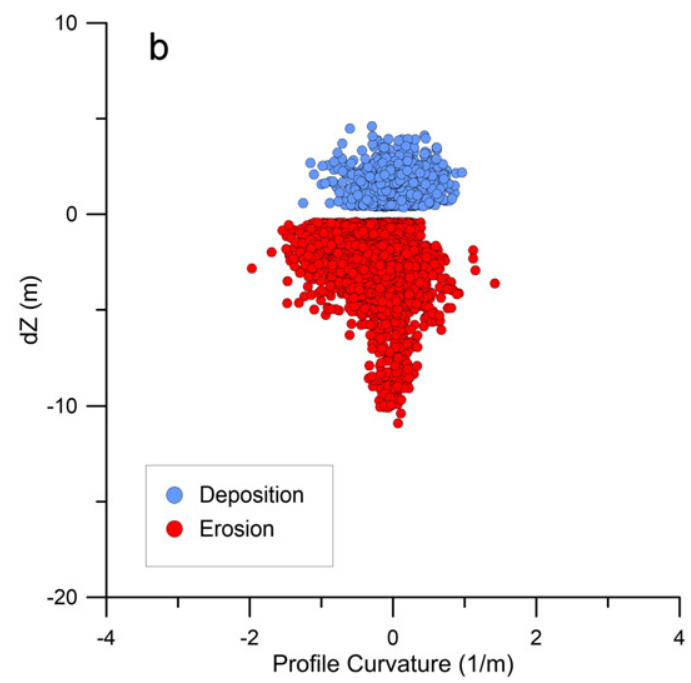


The temporal evolution of planform curvature can be also observed by plotting curvature values derived from the 2005 DTM against values calculated on the 2011 DTM. Fig. 10 shows the 2005 versus 2011 plan form curvature for the Gadria and Strimm catchments. The plot high lights that erosion dominates the upper quadrants (I and II in Fig. 10) indicating the increase of concavity and the transition from convex to concave morphology, while deposition prevails in the lower right quad rant (IV in Fig. 10) expressing the reverse change in morphology. Both erosion and deposition patterns characterize the lower left quadrant (III in Fig. 10) depicting areas of permanent convex morphology.

Similar results characterize profile curvature variations in the 2005 2011 time window. In both study areas, erosion prevails on surfaces that experienced an increase of concave morphology (38.5\% and 47\% for Gadria and Strimm basins, respectively) or where convex surfaces be came concave (19.8\% and $18.6 \%$ for Gadria and Strimm basins, respec tively). Deposition mostly occurs on previously concave locations that became convex (39.7\% for Gadria and 31.4\% for Strimm basin). Also in the case of profile curvature, the plot showing the curvature changes oc curred from 2005 to 2011 helps in visual identifying the main trend of erosion and deposition (Fig. 11 shows profile curvature data for the Gadria and Strimm catchments). In this case, erosion and deposition seem to have a more distinct pattern with erosion dominating the lower quadrants (III and IV in Fig. 11) characterized by unchanged con cave morphology and by a variation from convex to concave curvature and deposition prevailing on the upper ones (I and II in Fig. 11) indicat ing persistence of and transition to convex morphology.

In both study areas, erosion prevails on surfaces that experienced persistency of concave curvature for both planform and profile curvature. Sediment deposition mostly occurs to convex surfaces, especially due to the filling of previously convex areas. The observed variations of curvatures are generally in accordance with the expected dynamics of these processes. Indeed, incision of channel beds and gullying of unchannelized valleys enhance already existing concavities, while bank failures and incision of alluvial deposits may produce concavities in previously flat/convex surfaces (Fig. 12). In contrast, sediment depo sition mostly occurs on flat or convex (lateral levees along debris flow channel and debris flow lobes) topography, without changing the curvature of these areas, and may fill channel and gullies, obliterating previous concavity.

Complex interactions between the initial topography and erosion and deposition occurring in the time interval between the two LiDAR surveys may explain less obvious curvature changes. For instance, bed aggradation may not alter the concave planform curvature of a channel (Fig. 13). Conversely, the progressive dissection of a slope may produce local convexities (e.g., ridges) on a terrain undergoing an overall nega tive variation in elevation (Fig. 4).

\section{Discussion}

\subsection{Comparison between DoD and field surveys}

When comparing DoD with post event field observations, it is im portant to bear in mind the limitations of these approaches when applied to erosion and sediment yield evaluation. Low DTMs accuracy, as in those deriving from regional scale ALS, can negatively affect the accu racy of DoD analysis. TLS derived DTMs easily attain higher accuracy (e.g., Theule et al., 2012; Blasone et al., 2014), but they are difficult to implement at the catchment scale in rugged mountain areas. Moreover, DoD based estimation of erosion and sediment deposition usually en compasses several events, unless LiDAR topographic surveys are repeat ed after each storm event, a task that is extremely onerous and costly to pursue over large areas. A basic limitation of field surveys after floods and debris flows in mountain catchments is that measurements of sed iment deposits are usually limited to the larger ones only, thus neglecting smaller and less accessible deposits whose total volume can make up a relevant part of the sediment budget at the catchment
Table 5

Variations in planform curvature for areas undergoing topographic changes in the Gadria and Strimm catchments.

\begin{tabular}{llllll}
\hline $\begin{array}{llllll}\text { Morphological } \\
\text { variation }\end{array}$ & \multicolumn{2}{l}{ Gadria } & & \multicolumn{2}{l}{ Strimm } \\
\cline { 2 - 3 } \cline { 5 - 6 } \cline { 5 - 6 } & $\begin{array}{l}\text { Erosion } \\
\text { (\%) }\end{array}$ & $\begin{array}{l}\text { Deposition } \\
(\%)\end{array}$ & & $\begin{array}{l}\text { Erosion } \\
(\%)\end{array}$ & $\begin{array}{l}\text { Deposition } \\
(\%)\end{array}$ \\
\hline Convex to convex & 13.0 & 23.7 & & 7.8 & 21 \\
Convex to concave & 9.5 & 4.9 & & 9.9 & 0.8 \\
Convex to flat & 7.6 & 2.9 & & 6.3 & 1.2 \\
Concave to concave & 45.0 & 20.7 & & 50.5 & 18.5 \\
Concave to convex & 0.9 & 25.1 & & 0.9 & 34.1 \\
Concave to flat & 2.9 & 7.6 & & 2.8 & 11.1 \\
Flat to convex & 2.2 & 11.0 & & 2.4 & 10.5 \\
Flat to concave & 12.5 & 2.4 & & 12.2 & 0.8 \\
Flat to flat & 6.4 & 1.7 & & 7.2 & 2.1 \\
\hline
\end{tabular}

scale. Structure from Motion (SfM) technique can greatly improve post event field estimates by providing a quantitative measurements of erosion and deposits and permits to track with high frequency geomorphic changes, especially when these take place in restricted areas that can be covered by unmanned aerial vehicles or ground coverage (Westoby et al., 2012; Theule et al., 2015).

Several reasons may explain why DoD estimates of erosion volumes are greater than post event field estimates (Table 4). DoD takes into ac count topographic variations caused by a wide range of geomorphic processes, not only debris flows and large floods that are the object of field surveys. On the other hand, DoD cannot capture small erosion pro cesses (e.g., chronic surficial erosion) characterized by depths of the same order of magnitude of the DoD error. Given the rather long time window (6 years), DoD was able to account for sediment output due to intra event sediment transport, i.e., bedload and suspended load transported by snowmelt runoff and small to moderate rainfall caused floods, whereas these processes are not considered by field measure ments, which are performed only after major events. Differences in po rosity, which is higher for in site debris (computed as erosion by DoD) than for sediment accumulation in the sediment trap at the catchments outlet (i.e., the source of data on debris flow volumes in post event field surveys for the study basins) also contribute to larger volumes in the DoD computation of erosion. Sediment discharged downstream of the filter check dam, although likely not very relevant for major events (Comiti et al., 2014), also contributes to lowering the volumes of post event field estimations.

In the case of Gadria and Strimm catchments, the higher DoD based erosion compared to the field estimates of sediment deposition can be also partly ascribed to some minor events that could have remained un detected by field surveys because they affected only the upper part of

Table

Variations in profile curvature for areas undergoing topographic changes in the Gadria and Strimm catchment.

\begin{tabular}{|c|c|c|c|c|}
\hline \multirow{2}{*}{$\begin{array}{l}\text { Morphological } \\
\text { variation }\end{array}$} & \multicolumn{2}{|l|}{ Gadria } & \multicolumn{2}{|l|}{ Strimm } \\
\hline & $\begin{array}{l}\text { Erosion } \\
(\%)\end{array}$ & $\begin{array}{l}\text { Deposition } \\
(\%)\end{array}$ & $\begin{array}{l}\text { Erosion } \\
(\%)\end{array}$ & $\begin{array}{l}\text { Deposition } \\
(\%)\end{array}$ \\
\hline Convex to convex & 15.9 & 25.6 & 11.1 & 17.1 \\
\hline Convex to concave & 19.8 & 8.1 & 18.6 & 6.9 \\
\hline Convex to flat & 7.0 & 3.0 & 3.8 & 3.0 \\
\hline Concave to concave & 38.5 & 6.3 & 47.0 & 24.8 \\
\hline Concave to convex & 4.6 & 39.7 & 6.3 & 31.4 \\
\hline Concave to flat & 2.8 & 7.5 & 3.2 & 7.3 \\
\hline Flat to convex & 2.4 & 6.9 & 2.5 & 5.3 \\
\hline Flat to concave & 7.5 & 2.1 & 6.5 & 3.2 \\
\hline Flat to flat & 1.6 & 0.8 & 1.1 & 0.9 \\
\hline
\end{tabular}



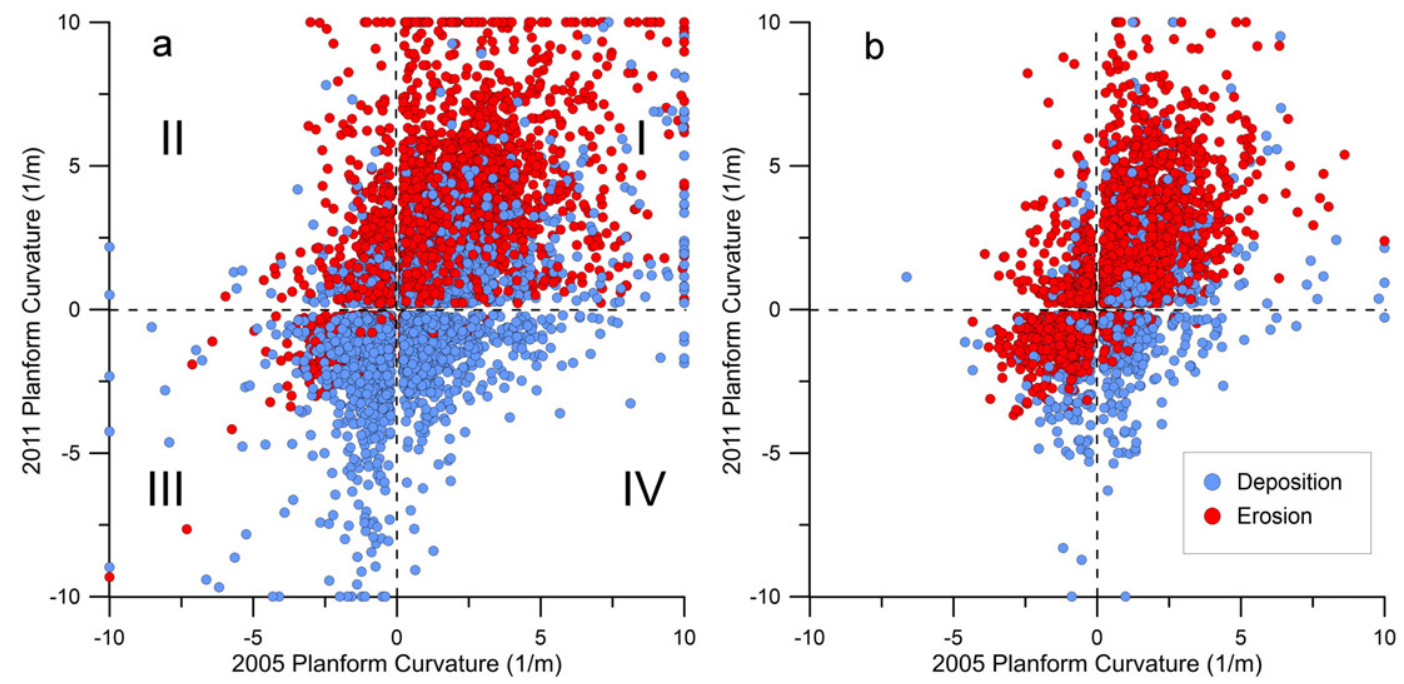

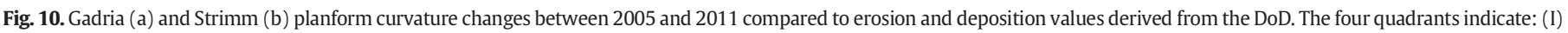
persistence of concavity; (II) transition from convexity to concavity; (III) persistence of convexity; (IV) transition from concavity to convexity.

the basins. Moreover, the comparison between volume estimates of DoD and the historical database are affected by uncertainties in assessing the relative contribution of Gadria and Strimm channels to sediment deposition in the retention basin at the catchments outlet in the case of events that involved both catchments as in the case of the one occurred on July 12, 2010 (Table 3).

Only for sediment deposition within the Strimm catchment field es timates provide a value larger than DoD $\left(11,700 \mathrm{~m}^{3}\right.$ versus 7539 $\mathrm{m}^{3}$, see Table 4$)$. This discrepancy might be related to two main reasons: (i) the personnel in charge of field surveys has reported that the volume of $10,000 \mathrm{~m}^{3}$ of debris flow deposits along the Strimm Creek for the event of July 12, 2010 (Table 3) is affected by major uncertainties and should be considered a roughly approximate estimation; (ii) an unquantified part of the deposited material was cleaned from the chan nel shortly after the event, and thus it is not represented in the 2011 DTM.

In this study we applied a critical threshold to filter out small changes in the DoD that cannot be reliably assumed to be "real" (i.e., different from errors). As observed by James et al. (2012), this filtering process may discard extensive small real changes that are cumulatively impor tant. It follows that DoD analysis may have underestimated erosion

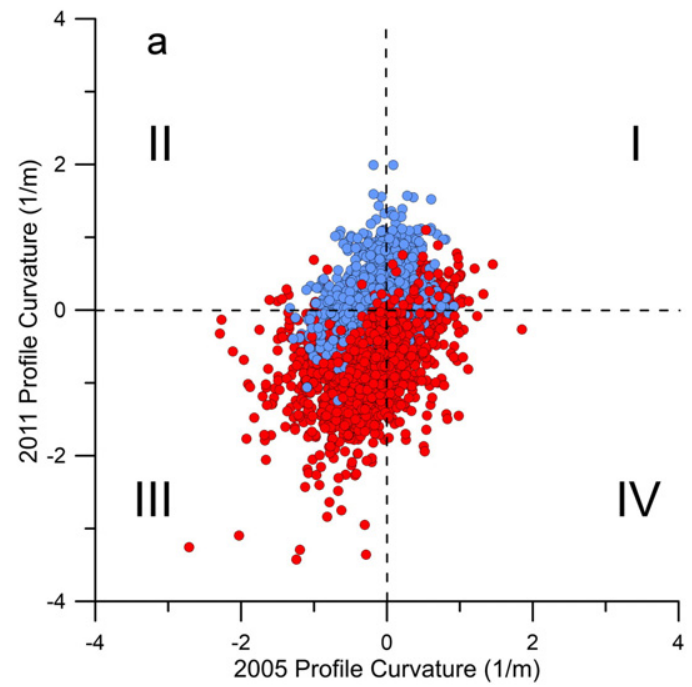

and deposition. To limit this issue, we chose to apply a minimum level of detection on DoD analysis based on a spatially variable assessment of DTMs uncertainty that is useful to recover some information on low magnitude erosion and deposition especially in low slope areas. The need of taking into account DTMs uncertainty and its propagation into DoD is confirmed by gross overestimations resulting from raw differencing of 2011 and 2005 DTMs. Total erosion and within catchment deposition computed by means of raw DTMs differencing for the Gadria amount to $471,893 \mathrm{~m}^{3}$ and $55,685 \mathrm{~m}^{3}$, respectively. In the Strimm, erosion and within catchment deposition are $147,617 \mathrm{~m}^{3}$ and $37,353 \mathrm{~m}^{3}$. Such high values, which exceed by more of three times post event field estimates, would be associated to areal extent of erosion and deposition much larger than those observed in the field and on aerial photographs, and point to the need for thresholding the DoD in order to achieving realistic values of erosion and sediment yield, especially when using DTMs of different quality and accuracy.

DoD analysis also enables estimating catchment sediment yield in the investigated time window. In order to determine sediment yield, sediment output from the catchment, computed by subtracting the vol ume of the deposits within the catchment from the total erosion volume derived from DoD, was divided by catchment area and the number of

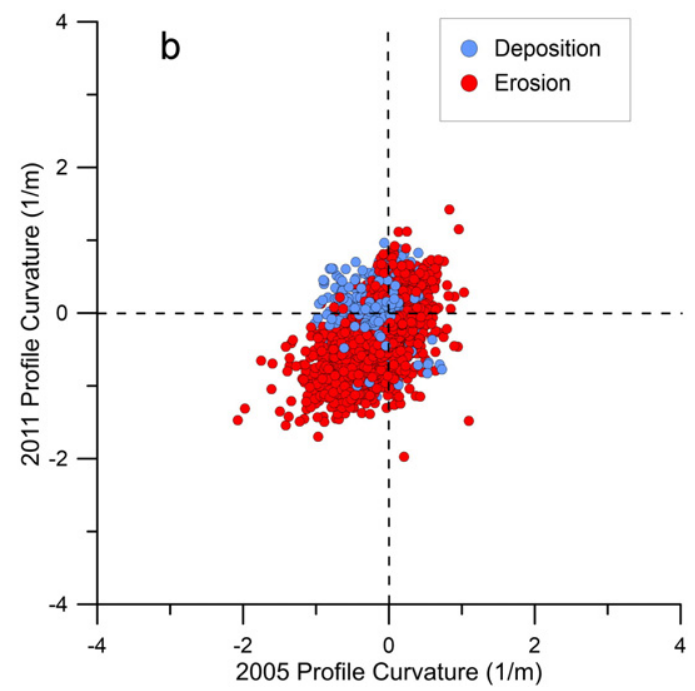

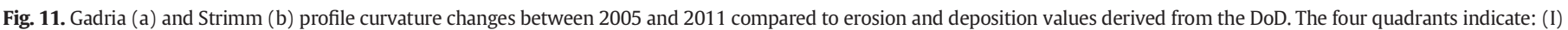
persistence of convexity; (II) transition from concavity to convexity; (III) persistence of concavity; (IV) transition from convexity to concavity. 


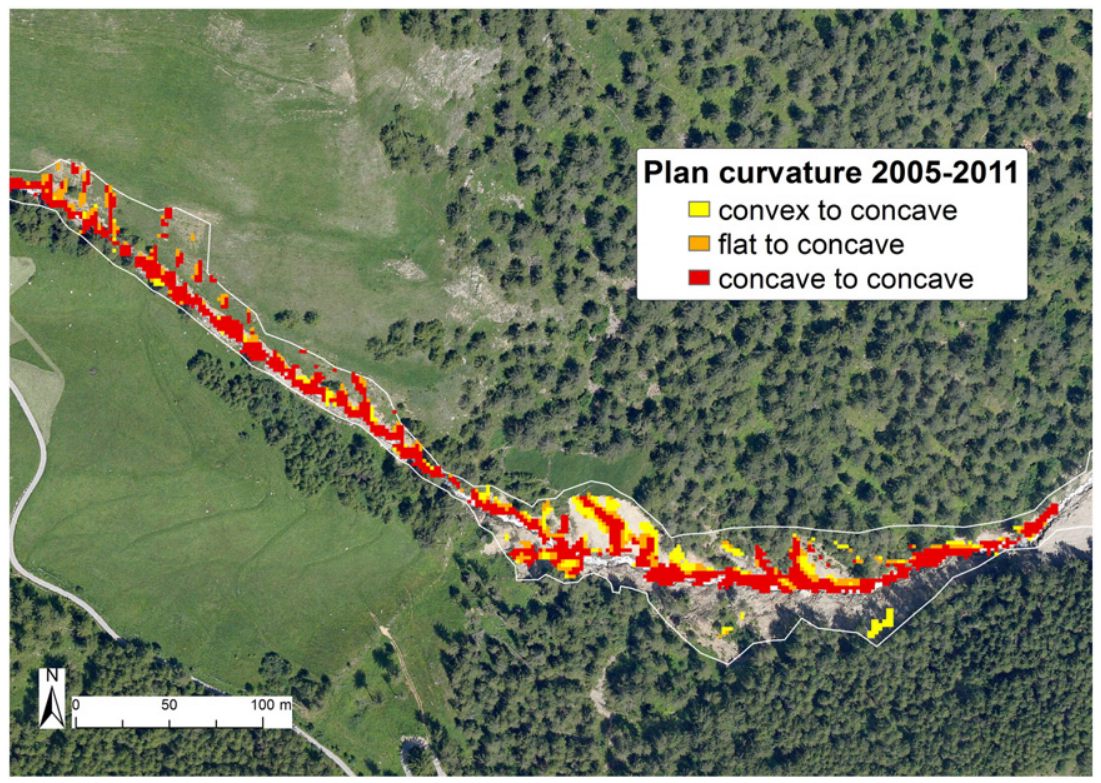

Fig. 12. Erosion along a steep channel reach (downstream-most reach of the Strimm Creek) is characterized by persistency of concavity and transformation of flat or convex areas into concave ones.

years between the two LiDAR survey. Compared to Strimm Creek, Gadria produced a higher amount of sediment with a sediment yield of about $5200 \mathrm{~m}^{3} \mathrm{~km}^{-2} \mathrm{y}^{-1}$ compared to the sediment yield of Strimm Creek (around $1000 \mathrm{~m}^{3} \mathrm{~km}^{-2}$ year ${ }^{-1}$ ). The magnitude of sediment yield in the Gadria basin is remarkable even for an active debris flow catchment in the context of the Upper Adige River basin (Brardinoni et al., 2012a).

In the lower Strimm Creek, within the period 2011 2014, Dell'Agnese et al. (2015) estimated bedload transport volumes by means of tracer based virtual velocity to be in the order of $200 \mathrm{~m}^{3}$ year -1 , which correspond to about $25 \mathrm{~m}^{3} \mathrm{~km}^{-2}$ year $^{-1}$. Such a low bedload yield compared to sediment yield assessed by DoD for the 20052011 interval stems from the ordinary flow conditions which characterized the most recent years. Indeed, large transport events as the ones which were captured in the DoD analysis (more re markably the July 2010) did not occur during the tracer monitoring study carried out by Dell'Agnese et al. (2015). This evidence stresses how long term monitoring activities are fundamental to obtain reliable estimates of sediment yield in mountain catchments (Mao et al., 2009).

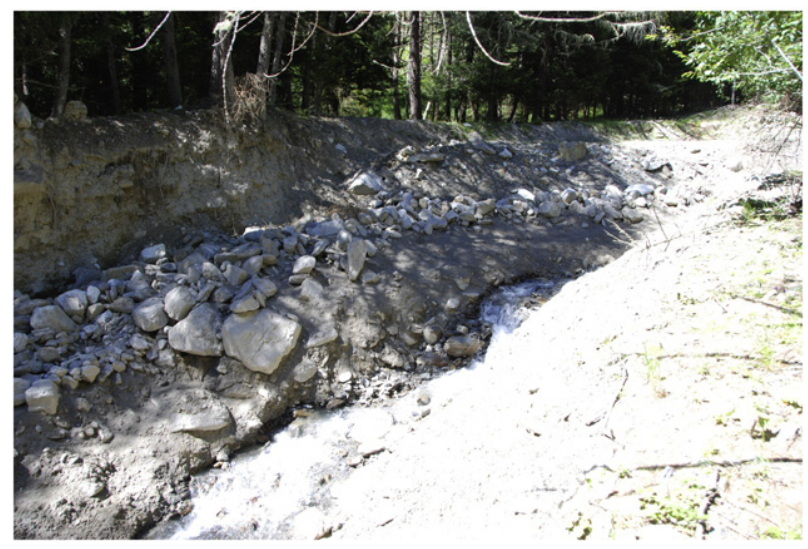

Fig. 13. Example of permanence of concavity in deposition areas: aggradation of channel bed in a confined reach.
5.2. Relationships between topographic changes and geomorphometric parameters

Area slope relationships (Fig. 7) clearly reflect the difference between the studied catchments in terms of sediment routing efficiency and are consistent with the patterns of sediment connectivity observed in the two catchments. Cavalli et al. (2013) showed that the Gadria catchment features overall higher values and a more homogeneous pat tern of sediment connectivity measured by a GIS based index they proposed than the Strimm basin. Such connectivity index, which ex presses the expected propensity for sediment to reach the catchment outlet or the main channel from any location, attains high values (i.e., well connected cells) also in the upper part of the Gadria, which is characterized by steep gullies and deeply incised debris flow chan nels. This spatial pattern of sediment connectivity is consistent with the Gadria slope area relationship (Fig. 7a), which shows that erosion processes affect most of the channel network, whereas deposits gener ally occur essentially in relatively low slope reaches, prevailingly locat ed at the confluence with the tributaries, where the valley bottom widens up, or in correspondence of check dams, which favor channel slope reduction. Conversely, the upper part of the Strimm basin pre sents a hanging valley poorly connected to the basin outlet. Featuring a discontinuous and poorly organized channel network where bedload transport is rather limited too (Dell'Agnese et al., 2015). This can explain the lack of erosion in the area slope plot between $0.4 \mathrm{~km}^{2}$ and $4 \mathrm{~km}^{2}$ drainage areas. A gradual increase of connectivity was observed by Cavalli et al. (2013) in the middle and lower parts of the Strimm catch ment, where erosion effectively took place within the analyzed period in the right side steep tributaries illustrated in Fig. 3a and along the main channel, mostly as a result of debris flow processes.

\section{Conclusions}

The comparison of DoD with post event field surveys has enabled to test the consistency of two independent estimates of erosion and depo sition associated to debris floods and debris flows in two Alpine catch ments. The overall agreement is satisfactory, with DoD computed volumes following the variability of sediment volumes from post event field surveys both between the two studied catchments, and be tween the components on sediment budget (within catchment 
deposition and total erosion). The differences between DoD and post event field estimates are explained by the inherent approximations of the two approaches. The gross overestimation of erosion and deposition resulting from raw differencing of the two DTMs points out the need for thresholding the DoD to discriminate real changes from noise, and the method applied here (Wheaton et al., 2010), which accounts for the spatial variability of DTM uncertainties, has proved effective.

The consistency of DoD with post event estimates encourages the integration of these two approaches, whose combined application may permit overcoming the limitations intrinsic to the individual methods. The advantages of the integration of DoD with post event field documentation can be summarized as follows: (i) distributed representation of erosion and deposition at the catchment scale (DoD) is combined with detailed temporal assessment of events achieved by means of field surveys; (ii) DoD may highlight erosion and deposition areas that remained unsurveyed during post event observations; (iii) post event surveys enable expert judgement of phenomena that may increase the informative content of DoD estimates of erosion and depo sition, thus allowing to link topographic variations to the actual trans port processes.

Finally, consistent relationships were found between short term landform evolution, represented by DoD computed topographic chang es, and erosion deposition processes, expressed by values and varia tions of geomorphometric parameters easily derivable from DTMs (upslope area, local slope, planform and profile curvature).

Given the increasing availability of high resolution topography thanks to emerging low cost techniques of data acquisition (e.g., SfM), the suggested approach for analyzing DoD grids will find increasing ap plications in future studies addressing geomorphic change detection in mountain catchments.

\section{Acknowledgments}

The research for this paper was carried out in the frame of SedAlp Project (83 43 AT, European Territorial Cooperation Alpine Space Programme 2007 2013) and as part of the PhD work of Beatrice Goldin (PhD Course Land Environment Resources and Health, University of Padova), funded by CNR IRPI (agreement no. 2169 dated 04/08/2011). The authors wish to thank the Department of Hydraulic Works of the Autonomous Province of Bolzano for providing data on post event field surveys, Stefano Crema for helping in processing area and slope data, the Guest Editor, Frédéric Liébault, and two anonymous referees for their constructive comments on the manuscript.

\section{Appendix A. Supplementary data}

Supplementary data associated with this article can be found in the online version, at doi: http://dx.doi.org/10.1016/j.geomorph.2016. 04.009. These data include the Google map of the study areas described in this article.

\section{References}

Abermann, J., Fischer, A., Lambrecht, A., Geist, T., 2010. On the potential of very highresolution repeat DEMs in glacial and periglacial environments. Cryosphere 4, 53 65. http://dx.doi.org/10.5194/tc-4-53-2010.

Anders, N.S., Seijmonsbergen, A., Bouten, W., 2013. Geomorphological change detection using object-based feature extraction from multi-temporal LiDAR data. IEEE Geosci. Remote Sens. Lett. 10, 1587-1591. http://dx.doi.org/10.1109/LGRS.2013.2262317.

Baldo, M., Bicocchi, C., Ciocchini, U., Giordan, D., Lollino, G., 2009. LIDAR monitoring of mass wasting processes: the Radicofani landslide, Province of Siena, Central Italy,

Geomorphology. 105, 193-201.

Bennett, G.L., Molnar, P., Eisenbeiss, H., McArdell, B.W., 2012. Erosional power in the Swiss Alps: characterization of slope failure in the Illgraben. Earth Surf. Process. Landf. 37, 1627-1640. http://dx.doi.org/10.1002/esp.3263.

Berger, C., McArdell, B.W., Schlunegger, F., 2011. Direct measurement of channel erosion by debris flows, Illgraben, Switzerland. J. Geophys. Res. Earth Surf. 116, F01002. http://dx.doi.org/10.1029/2010JF001722.
Blasone, G., Cavalli, M., Marchi, L., Cazorzi, F., 2014. Monitoring sediment source areas in a debris-flow catchment using terrestrial laser scanning. Catena 123, 23-36.

Bossi, G., Cavalli, M., Crema, S., Frigerio, S., Quan Luna, B., Mantovani, M., Marcato, G., Schenato, L., Pasuto, A., 2015. Multi-temporal LiDAR-DTMs as a tool for modelling a complex landslide: a case study in the Rotolon catchment (eastern Italian Alps). Nat. Hazards Earth Syst. Sci. 15, 715-722. http://dx.doi.org/10.5194/nhess-15-715-2015.

Brardinoni, F., Hassan, M.A., Rollerson, T., Maynard, D., 2009. Colluvial sediment dynamics in mountain drainage basins. Earth Planet. Sci. Lett. 284, 310-319.

Brardinoni, F., Church, M., Simoni, A., Macconi, P., 2012a. Lithologic and glacially conditioned controls on regional debris-flow sediment dynamics. Geology 40, 455-458.

http://dx.doi.org/10.1130/G33106.1.

Brardinoni, F., Hassan, M.A., 2006. Glacial erosion, evolution of river long profiles, and the organization of process domains in mountain drainage basins of coastal British Co-lumbia. J. Geophys. Res. Earth Surf. 111, F01013. http:// dx.doi.org/10.1029/2005JF000358.

Brardinoni, F., Perina, E., Bonfanti, G., Falsitta, G., Agliardi, F., 2012b. Linking highresolution geomorphic mapping, sediment sources, and channel types in a formerly glaciated basin of northeastern Alto-Adige/Sudtirol, Italy. Geophysical Research Ab-stracts 14, EGU2012-13692, EGU General Assembly 2012.

Brasington, J., Langham, J., Rumsby, B., 2003. Methodological sensitivity of morphometric estimates of coarse fluvial sediment transport. Geomorphology 53 (3-4), 299-316. Brasington, J., Rumsby, B.T., McVey, R.A., 2000. Monitoring and modelling morphological change in a braided gravel-bed river using high resolution GPS-based survey. Earth Surf. Process. Landf. 25 (9), 973-990.

Bremer, M., Sass, O., 2012. Combining airborne and terrestrial laser scanning for quantifying erosion and deposition by a debris flow event. Geomorphology 138 (1), 49-60. Brewer, P.A., Passmore, D.G., 2002. Sediment budgeting techniques in gravel bed rivers. In: J, S., Frostick, L. (Eds.), In Sediment Flux to Basins: Causes, Controls and Consequences, Special Publication 191. Geological Society, London, pp. 97-113.

Bull, J.M., Miller, H., Gravley, D.M., Costello, D., Hikuroa, D.C.H., Dix, J.K., 2010. Assessing debris flows using LIDAR differencing: 18 May 2005 Matata event, New Zealand. Geo-morphology 124, 75-84. http://dx.doi.org/10.1016/j.geomorph.2010.08.011.

Campana, D., Marchese, E., Theule, J., Comiti, F., 2014. Channel degradation and restoration of an alpine river and related morphological changes. Geomorphology 221,

230-241. http://dx.doi.org/10.1016/j.geomorph.2014.06.016.

Cavalli, M., Marchi, L., 2008. Characterisation of the surface morphology of an alpine alluvial fan using airborne LiDAR. Nat. Hazards Earth Syst. Sci. 8, 323-333. http:// dx.doi. org/10.5194/nhess-8-323-2008.

Cavalli, M., Trevisani, S., Comiti, F., Marchi, L., 2013. Geomorphometric assessment of spatial sediment connectivity in small alpine catchments. Geomorphology 188, 31-41.

http://dx.doi.org/10.1016/j.geomorph.2012.05.007.

Coe, J.A., Glancy, P.A., Whitney, J.W., 1997. Volumetric analysis and hydrologic characterization of a modern debris flow near Yucca Mountain, Nevada. Geomorphology 20 11-28.

Comiti, F., Marchi, L., Macconi, P., Arattano, M., Bertoldi, G., Borga, M., Brardinoni, F., Cavalli, M., D'Agostino, V., Penna, D., Theule, J., 2014. A new monitoring station for de-bris flows in the European Alps: first observations in the Gadria basin. Nat Hazards 73 (4), 1175-1198. http://dx.doi.org/10.1007/s11069-014-1088-5.

Corsini, A., Borgatti, L., Coren, F., Vellico, M., 2007. Use of multitemporal airborne LiDAR surveys to analyse post-failure behaviour of earthslides. Can. J. Remote. Sens. 33,

116-120.

Croke, J., Todd, P., Thompson, C., Watson, F., Denham, R., Khanal, G., 2013. The use of multi temporal LiDAR to assess basin-scale erosion and deposition following the catastrophic January 2011 Lockyer flood, SE Queensland, Australia. Geomorphology 184, 111-126. http://dx.doi.org/10.1016/j.geomorph.2012.11.023.

Dell'Agnese, A., Brardinoni, F., Toro, M., Mao, L., Engel, M., Comiti, F., 2015. Tracing bedload transport in a high-elevation, formerly-glaciated mountain basin. Earth Surf. Dyn.

Discuss. 3, 417-458. http://dx.doi.org/10.5194/esurfd-3-417-2015.

Delong, S.B., Prentice, C.S., Hilley, G.E., Ebert, Y., 2012. Multitemporal ALSM change detection, sediment delivery, and process mapping at an active earthflow. Earth Surf. Pro-cess. Landf. 37, 262-272.

Fuller, I.C., Large, A.R.G., Charlton, M.E., Heritage, G.L., Milan, D.J., 2003. Reach-scale sediment transfers: an evaluation of two morphological budgeting approaches earth surf.

Process. Landf. 28 (8), 889-903.

Habler, G., Thöni, M., Grasemann, B., 2009. Cretaceous metamorphism in the Austroalpine Matsch Unit (Eastern Alps): the interrelation between deformation and chemical equilibration processes. Mineral. Petrol. 97 (3-4), 149-171.

Ham, D.G., Church, M., 2000. Bed-material transport estimated from channel morphodynamics: Chilliwack River, British Columbia. Earth Surf. Process. Landf. 25, $1123-1142$.

Hengl, T., Reuter, H.I. (Eds.), 2009. Geomorphometry: Concepts, Software, Applications, Developments in Soil Science. Elsevier.

Jaboyedoff, M., Oppikofer, T., Abellán, A., Derron, M.-H., Loye, A., Metzger, R., Pedrazzini, A., 2012. Use of LIDAR in landslide investigations: a review. Nat. Hazards 61, 5-28. http://dx.doi.org/10.1007/s11069-010-9634-2.

James, L.A., Hodgson, M.E., Ghoshal, S., Latiolais, M.M., 2012. Geomorphic change detection using historic maps and DEM differencing: the temporal dimension of geospatial analysis. Geomorphology 137, 181-198. http://dx.doi.org/10.1016/ j.geomorph.2010. 10.039 .

Joerg, P.C., Morsdorf, F., Zemp, M., 2012. Uncertainty assessment of multi-temporal airborne laser scanning data: a case study on an Alpine glacier. Remote Sens. Environ. 127, 118-129. http://dx.doi.org/10.1016/j.rse.2012.08.012

Karimi, N., Farokhnia, A., Shishangosht, S., Elmi, M., Eftekhari, M., Ghalkhani, H., 2012. Elevation changes of Alamkouh glacier in Iran since 1955, based on remote sensing data. Int. J. Appl. Earth Obs. Geoinf. 19, 45-58. http://dx.doi.org/10.1016/ j.jag.2012. 04.009. 
Lallias-Tacon, S., Liébault, F., Piégay, H., 2014. Step by step error assessment in braided river sediment budget using airborne LiDAR data. Geomorphology 214, 307-323.

http://dx.doi.org/10.1016/j.geomorph.2014.02.014

Lane, S.N., Richards, K.S., Chandler, J.H., 1994. Developments in monitoring and modelling small-scale river bed topography. Earth Surf. Process. Landf. 19, 349-368. http:// dx. doi.org/10.1002/esp.3290190406.

Lane, S.N., Westaway, R.M., Hicks, D.M., 2003. Estimation of erosion and deposition volumes in a large, gravel-bed, braided river using synoptic remote sensing. Earth Surf Process. Landf. 28, 249-271. http://dx.doi.org/10.1002/esp.483.

Mao, L., Cavalli, M., Comiti, F., Marchi, L., Lenzi, M.A., Arattano, M., 2009. Sediment transfer processes in two Alpine catchments of contrasting morphological settings. J. Hydrol. 364, 88-98. http://dx.doi.org/10.1016/j.jhydrol.2008.10.021.

Martin, Y., Church, M., 1995. Bed-material transport estimated from channel surveys Vedder River, British-Columbia. Earth Surf. Process. Landf. 20 (4), 347-361.

Mathys, N., Brochot, S., Meunier, M., Richard, D., 2003. Erosion quantification in the small marly experimental catchments of Draix (Alpes de Haute Provence, France). Calibra-tion of the ETC rainfall-runoff-erosion model. CATENA. Gully Erosion and Global Change 50, 527-548.

McArdell, B.W., Bartelt, P., Kowalski, J., 2007. Field observations of basal forces and fluid pore pressure in a debris flow. Geophys. Res. Lett. 34 (7), L07406.

McCoy, S.W., Kean, J.W., Coe, J.A., Staley, D.M., Wasklewicz, T.A., Tucker, G.E., 2010. Evolution of a natural debris flow: in situ measurements of flow dynamics, video imagery, and terrestrial laser scanning. Geology 38, 735-738. http://dx.doi.org/10.1130/ G30928.1.

McKean, J., Roering, J., 2004. Objective landslide detection and surface morphology mapping using high-resolution airborne laser altimetry. Geomorphology 57, 331-351.

http://dx.doi.org/10.1016/S0169-555X(03)00164-8.

Montgomery, D.R., Foufoula-Georgiou, E., 1993. Channel network source representation using digital elevation models. Water Resour. Res. 29, 3925-3934. http:// dx.doi.org/ 10.1029/93WR02463.

Picco, L., Mao, L., Cavalli, M., Buzzi, E., Rainato, R., Lenzi, M.A., 2013. Evaluating short-term morphological changes in a gravel-bed river using terrestrial laser scanner. Geomor-

phology 201, 323-334. http://dx.doi.org/10.1016/j.geomorph.2013.07.007. Rainato, R.,

Mao, L., García-Rama, A., Picco, L., Cesca, M., Vianello, A., Preciso, E., Scussel, G.R., Lenzi, M.A., 2016. Three decades of monitoring in the Rio Cordon instrumented basin: sediment budget and temporal trend of sediment yield. Geomorphology http://dx.doi.org/10.1016/j.geomorph.2016.03.012.

Sailer, R., Bollmann, E., Ebe, V., Girstmair, A., Klug, C., Rieg, L., Spross, M., Stötter, J., 2012. The potential of repeat airborne lidar for the analysis of geomorphic process dynamics in mountain terrain. AGU Fall Meet. Abstr. 23, 0893.

Schaffrath, K.R., Belmont, P., Wheaton, J.M., 2015. Landscape-scale geomorphic change detection: quantifying spatially variable uncertainty and circumventing legacy data iss

09.020.
Scheidl, C., Rickenmann, D., Chiari, M., 2008. The use of airborne LiDAR data for the anal-

sues. Geomorphology 250, 334-348. http://dx.doi.org/10.1016/j.geomorph.2015 ysis of debris flow events in Switzerland. Nat. Hazards Earth Syst. Sci. 8, 1113-1127.

Tarboton, D.G., 1997. A new method for the determination of flow directions and upslope areas in grid digital elevation models. Water Resour. Res. 33, 309-319.

Tarolli, P., Dalla Fontana, G., 2009. Hillslope to valley transition morphology: new opportunities from high resolution DTMs. Geomorphology 113, 47-56.

Tarolli, P., 2014. High-resolution topography for understanding earth surface processes: opportunities and challenges. Geomorphology 216, 295-312. http://dx.doi.org/10. 1016/j.geomorph.2014.03.008

Taylor, J., 1997. An Introduction to Error Analysis: The Study of Uncertainties in Physical Measurements. Second edition. University Science Books, Sausalito, California Second Edition Edition, 327 pp.

Theule, J., Bertoldi, G. Comiti, F. Macconi, P., Mazzorana, B. 2015. Exploring topographic methods for monitoring morphological changes in mountain channels of different size and slope. Geophysical Research Abstracts 17, EGU 2015-8893, EGU General As-sembly 2015.

Theule, J.I., Liébault, F., Loye, A., Laigle, D., Jaboyedoff, M., 2012. Sediment budget monitoring of debris-flow and bedload transport in the Manival Torrent, SE France. Nat. Hazards Earth Syst. Sci. 12, 731-749. http://dx.doi.org/10.5194/nhess-12-731-2012.

Trevisani, S., Cavalli, M., Marchi, L., 2012. Surface texture analysis of a high-resolution DTM: interpreting an alpine basin. Geomorphology 161-162, 26-39. http:// dx.doi. org/10.1016/j.geomorph.2012.03.031.

Vale, S.S., Fuller, I.C., 2009. Morphological budgeting in the Motueka River: analysis of technique. Geoscience 2009 (1), 1-17.

Vericat, D., Smith, M.W., Brasington, J., 2014. Patterns of topographic change in subhumid badlands determined by high resolution multi-temporal topographic

surveys. Catena 120, 164-176. http://dx.doi.org/10.1016/j.catena.2014.04.012

Wack, R., Selzl, H., 2005. Laser DTM generation for South-Tyrol and 3D visualization.

Pro-ceedings of the ISPRS Workshop "Laser scanning 2005". ISPRS, Enschede, the Netherlands, pp. 48-53.

Westoby, M.J., Brasington, J., Glasser, N.F., Hambrey, M.J., Reynolds, J.M., 2012. “Structurefrom-Motion" photogrammetry: a low-cost, effective tool for geoscience applications. Geomorphology 179, 300-314. http://dx.doi.org/10.1016/j.geomorph.2012.08.021.

Wheaton, J.M., Brasington, J., Darby, S.E., Sear, D.A., 2010. Accounting for uncertainty in DEMs from repeat topographic surveys: improved sediment budgets. Earth Surf. Pro-cess. Landf. 35, 136-156. http://dx.doi.org/10.1002/esp.1886.

Wood, J.D., 1996. The geomorphological characterisation of digital elevation models (PhD Thesis) University of Leicester, UKhttp://www.soi.city.ac.uk/ jwo/phd. 